\title{
Neurological Symptoms Among Sri Lankan Farmers Occupationally Exposed to Acetylcholinesterase-Inhibiting Insecticides
}

\author{
Lidwien A.M. Smit, MSc, ${ }^{1,2 *}$ Berna N. van-Wendel-de-Joode, ${ }^{\text {MSc, }}{ }^{2,3}$ Dick Heederik, ${ }^{2}{ }^{2}{ }^{2}$ \\ Roshini J. Peiris-John, MBBs, $^{4}$ and Wim van der Hoek, MD, MSc ${ }^{1}$
}

\begin{abstract}
Background In many agricultural districts in Sri Lanka, pesticide poisoning is a leading cause of death. This study aims to evaluate the impact of pesticide use on Sri Lankan farmers' health.

Methods A total of 260 subjects were surveyed in both a low and a high exposure period. Acetylcholinesterase activity was measured and data on symptoms were collected with questionnaires.

Results Twenty-four percent of surveyed farmers had suffered at least once from acute pesticide poisoning. Farmers showed significantly more inhibition of cholinesterase activity than controls. Acute symptoms indicative for exposure to cholinesterase-inhibiting pesticides were associated with farming and a higher degree of cholinesterase suppression (more than 13\% inhibition). Integrated Pest Management (IPM) training seemed to result in less insecticide use, and less cholinesterase inhibition.

Conclusions Our results suggest that occupational acetylcholinesterase-inhibiting insecticide exposures have a negative impact on Sri Lankan farmers' health. Overall reduction in pesticide use seems the best option to protect farmers from the adverse effects of pesticides. Am. J. Ind. Med. 44:254-264, 2003. ๑ 2003 Wiley-Liss, Inc.
\end{abstract}

KEY WORDS: pesticide exposure; acetylcholinesterase inhibition; neurological symptoms; IPM; Sri Lanka

\section{INTRODUCTION}

Pesticide poisoning is a major health problem in Sri Lanka [Jeyaratnam et al., 1982; Eddleston et al., 1998; Van der Hoek et al., 1998; Fernando and Hewagalage, 1999].

\footnotetext{
1 International Water Management Institute, Colombo, Sri Lanka

${ }^{2}$ Institute for Risk Assessment Sciences, Division of Environmental and Occupational Health, University Utrecht, Utrecht, The Netherlands

${ }^{3}$ Department of Chemical Exposure Assessment, TNO Chemistry, Zeist, The Netherlands

${ }^{4}$ Department of Physiology, Faculty of Medical Sciences, University of Sri Jayewardenapura, Gangodawila, Nugegoda, Sri Lanka

Contract grant sponsor: International Development Research Centre, Ottawa, Canada.

*Correspondence to: Lidwien Smit, Institute for Risk Assessment Sciences, University Utrecht, P.O. Box 80176, 3508TD Utrecht, The Netherlands.

E-mail: I.smit@iras.uu.nl

Accepted 2 June 2003

DOI 10.1002/ajim.10271. Published online in Wiley InterScience

(www.interscience.wiley.com)
}

In many agricultural districts, pesticide poisoning is the leading cause of death [Ministry of Health, 2001]. Most clinically documented acute poisoning cases in Sri Lanka are deliberate (suicide) and occur among young adults [Van der Hoek et al., 1998]. Pesticide poisoning due to occupational exposure is poorly documented but is assumed to be common. One report claims that yearly five out of every 1,000 agricultural workers in Sri Lanka are hospitalized due to pesticide poisoning of occupational origin [Jeyaratnam et al., 1982]. However, many additional, less severe, cases of occupational poisoning may not require hospitalization and are, therefore, not included in the total cases reported.

Since the 1980s, organophosphate compounds have been the principal means of agricultural pest control throughout the world [Stephens et al., 1995]. Organophosphates and $\mathrm{N}$-methyl carbamate insecticides have well-documented acute systemic effects largely mediated through cholinesterase inhibition leading to an overstimulation and then 
depression of the nervous system [Yuknavage et al., 1997]. Early symptoms of acute poisoning include weakness, nausea, vomiting, excessive sweating and salivation, headache, and difficulty in walking [Namba, 1971]. Severe poisoning may result in unconsciousness, pulmonary edema, respiratory failure, and death [Al-Shatti et al., 1997]. Single episodes of clinically significant organophosphate intoxication are associated with a persistent decline in neuropsychological functioning [Rosenstock et al., 1991]. Long-term, relatively low exposure to pesticides, particularly organophosphate insecticides, is increasingly suspected of causing similar effects on the nervous system [Stephens et al., 1995; Wesseling et al., 1997; London et al., 1998]. However, firm conclusions on neuropsychological effects of chronic exposure to pesticides are difficult to draw as information is scarce, particularly in developing countries [London et al., 1998; Tinoco-Ojanguren and Halperin, 1998; Maroni et al., 1999].

Farmers in Sri Lanka have knowledge of the existence of, and limited access to, personal protective devices when applying pesticides, although they rarely apply them. Protective devices are found to interfere with work practices, are uncomfortable in the hot, humid climate, and are time consuming to put on [Sivayoganathan et al., 1995; Van der Hoek et al., 1998]. In addition, the effectiveness of these devices may be inadequate due to penetration of pesticides through clothing and occlusion of exposed skin by gloves and clothing [Van Wendel de Joode et al., 1996; Meuling et al., 1997; Spruit and Van Puyvelde, 1998; Brouwer et al., 2000]. Van der Hoek et al. [1998] proposed alternative ecological methods of pest control within the context of Integrated Pest Management (IPM) as a strategy to reduce pesticide use in Sri Lanka. IPM makes full use of natural and cultural pest control processes and methods, and also involves a wide range of other practices aimed at growing a healthy crop. Farmers learn about the ecology of their fields and, as a result, they make and implement decisions, which are safe, productive, and sustainable. Chemical pesticides are used only where and when the above measures fail to keep pests below damaging levels [FAO Programme for Community IPM in Asia, 2001].

This study was part of an ongoing research project of the International Water Management Institute (IWMI) in the Uda Walawe Irrigation Scheme in southern Sri Lanka. The study was undertaken to evaluate the impact of different pesticide usage patterns on the health of farming families in the Uda Walawe Irrigation Scheme. The aims of study were: to assess (neurological) symptom prevalence in relation to occupational exposure to cholinesterase-inhibiting pesticides; to determine the extent of acetylcholinesterase inhibition in general farmers and IPM-farmers in a high exposure period compared with a control group; to investigate relationships between symptoms, acetylcholinesterase inhibition, and cholinesterase-inhibiting pesticide exposure.

\section{SUBJECTS AND METHODS}

\section{Study Population}

The study population consisted initially of 242 farmers (all smallholders), including 131 farmers trained in using IPM in paddy (unhusked rice) cultivation. IPM-farmers were recruited by selecting randomly from a list of farmers who had attended IPM demonstrations conducted by the Mahaweli Authority of Sri Lanka in the Uda Walawe Irrigation Scheme. Other farmers were matched within the same villages. A control group of 55 fishermen was recruited from a fishing community of the Uda Walawe reservoir. Of 55 controls, 27 had previously cultivated crops, one or more years ago (average time since cultivation was 8.1 years). Thirteen controls reported having household members who spray pesticides.

\section{Data Collection}

Data were collected with questionnaires and by measuring red blood cell acetylcholinesterase activity in two different periods (April-May 2000 and June-July 2000). The first period was in-between Maha (October to March) and Yala (May to August), the two agricultural seasons in Sri Lanka. This was presumably a low exposure period, and cholinesterase activity levels measured during this period were considered baseline values. A second round of data collection took place during Yala agricultural season, a high exposure period. Recruited farmers were requested to come to a central location in their village on a scheduled day to participate in the study. The rate of follow-up was $84.7 \%$ of the baseline population for farmers $(n=94), 93.1 \%$ for farmers trained in the use of IPM $(n=122)$, and $80.0 \%$ for controls $(n=44)$.

For each cholinesterase test $10 \mu \mathrm{l}$ of blood were obtained from a finger-prick sample. Erythrocyte acetylcholinesterase activity in whole blood and hemoglobin were measured with the Test-mate ChE Cholinesterase Test System (EQM Research, Inc., Cincinnati, OH). This World Health Organization (WHO) approved field kit is based on the method of Ellman et al. [1961]. Acetylcholinesterase activity is expressed in units (U)/g hemoglobin. The acetylcholinesterase activity in the high exposure period divided by the activity in the baseline period represents the change in acetylcholinesterase activity within an individual ([1 - change in acetylcholinesterase activity $] \times 100 \%=$ acetylcholinesterase inhibition).

Structured, pre-tested, questionnaires were used to obtain information on personal characteristics and pesticide handling. Subjects were asked questions on age, educational level, tobacco and alcohol consumption, IPM training, spray activities during the previous month, cropping details, pesticide expenditure, and spray activities during the entire 
Maha season (the previous season), use of protective measures and previous acute pesticide poisoning. The quetelet index (weight/square height $\left(\mathrm{kg} / \mathrm{m}^{2}\right)$ ) was calculated to determine the nutritional status of the subjects. A trained interviewer administered the questionnaires.

Furthermore two questionnaires were used to assess neurological symptoms. One of the two questionnaires was compiled of published signs and symptoms considered indicative for exposure to organophosphate and carbamate pesticides and assessed the prevalence of 16 acute symptoms experienced in the previous week [Namba, 1971; Derogatis and Spencer, 1982; Xue, 1987; Rosenstock et al., 1991; Rola and Pingali, 1993; Kishi et al., 1995; London et al., 1998]. Earache was added as a dummy symptom to control for bias. The second questionnaire consisted of 16 neurological symptoms derived from a previously validated Swedish 16item questionnaire (Q16) [Hogstedt et al., 1984; Lundberg et al., 1997]. These symptoms are considered indicative for long-term health effects (early neurological disorders) due to insecticide exposure. Three questions were adapted, as they were clearly not applicable to the Sri Lankan situation: 'do you often make notes about what you must remember?' and 'do you generally find it hard to get the meaning from reading newspapers and books' were rephrased because many farmers were illiterate, 'do you have problems with buttoning and unbuttoning' was modified because most farmers usually wear clothes without buttons. Constipation was used as dummy symptom. Questionnaires were translated into Sinhalese and back-translated into English by a different translator to check whether questions had been translated correctly. Questionnaires were tested in a pilot-study among 20 farmers. Ethical clearance of the study was obtained from the Ethical Committee, Faculty of Medical Sciences, University of Sri Jayewardenapura, Sri Lanka. Informed consent was obtained from all study subjects. Subjects who had any symptoms of poisoning were referred to the Embilipitiya Base Hospital for further treatment.

\section{Data Analysis}

Data from subjects who had participated in both surveys (baseline and Yala season) was analyzed with SPSS (version 8.0). Acetylcholinesterase activity and inhibition levels were compared using analysis of variance (ANOVA). Cox's proportional hazard regression was used to calculate symptom prevalence ratios adjusted for potentially confounding variables [Skov et al., 1998]. Additionally, outcomes of the symptom questionnaires were dichotomized at more than six symptoms according to Hogstedt et al. [1984] (Q16), and at the 75th percentile of the study population (acute neurological symptoms). Acute symptoms significantly related to cholinesterase inhibition were dichotomized as well, using a positive score for more than three symptoms as a cut off point ( 75 percentile). The effects of confounding variables on test outcomes of symptom prevalence for Cox's regression modeling were studied. Variables that changed the model meaningfully (entering the model with $P$-value $<$ 0.20 and changing the prevalence ratio at least $5 \%$ ) were kept. Results were adjusted for effects of age and years of education. Adjustment for sex, alcohol consumption, smoking habits, positive score for dummy symptoms, and acute pesticide poisoning in the past did not change results.

\section{RESULTS}

Table I shows personal characteristics of the study population. Some major differences were seen within the study groups of farmers, IPM-farmers and controls. No differences were observed between subjects available for follow-up and those who dropped out, with regard to personal characteristics, reported symptoms, and baseline acetylcholinesterase activity. IPM-farmers had received more frequent training in safe use of pesticides than other farmers had. IPM-farmers wore significantly more often headgear, long sleeved shirts, and long pants or a sarong during work in the field (chi-square, $P<0.05$ ) and ate and drank less often during pesticide application (chi-square, $P<0.005$ ). Personal protective equipment such as spectacles, footwear, gloves, or masks were rarely used in both groups of farmers.

Of all 216 farmers, 52 (24\%) reported having suffered at least once from an acute occupational pesticide poisoning in the past (Table II). IPM-farmers who reported an acute poisoning episode had more often sought medical treatment (visited a doctor or hospital) than general farmers (84 vs. $52 \%$ ). Frequently reported symptoms included fainting or unconsciousness, vomiting, nausea, blurred, or lost vision, headache, and dizziness.

A total of 514 spray operations (151 during the low exposure season and 363 during the high exposure season) were reported (see Appendix A). General farmers sprayed insecticides more often than IPM-farmers (71.3 vs. 53.7\% of all spray operations). Chlorpyrifos (an organophosphate insecticide) was the most frequently used pesticide amongst both groups of farmers. Many farmers had problems recalling names of pesticides they had used in the previous month. Data on average spraying time per hectare of cultivated agricultural land in the preceding Maha agricultural season (October to March 1999/2000) are summarized in Table III. According to these data IPM-farmers spent considerably less time per hectare on spraying insecticides than general farmers (10.9 vs. $58.9 \mathrm{hr}$; Mann-Whitney test; $P<0.001$ ). Much more time per hectare was spent on spraying insecticides on vegetables than on paddy and banana. The time spent on spraying herbicides was similar for both groups of farmers. The median expenditure on pesticides in the Maha season was 5,000 Rupees by general farmers and 3,000 Rupees by IPM-farmers ( 1 US $\$=80$ Rupees). 
TABLE I. Personal Characteristics of the Study Population of Sri Lankan Farmers, IPM-Farmers, and Fishermen (Controls)

\begin{tabular}{|c|c|c|c|}
\hline & General farmers $(n=94)$ & IPM-farmers $(n=122)$ & Controls $(n=44)$ \\
\hline Mean age in years $(\mathrm{SD})^{\star}$ & $38.4(11.8)$ & $50.5(11.9)$ & $34.8(10.1)$ \\
\hline Sex (\% male) & 94.7 & 87.7 & 97.7 \\
\hline Mean weight in $\mathrm{kg}(\mathrm{SD})^{\star}$ & $49.7(6.7)$ & $51.6(8.2)$ & $56.0(8.9)$ \\
\hline Mean height in $\mathrm{cm}(\mathrm{SD})^{\star}$ & $161.9(7.8)$ & $160.1(7.5)$ & $163.5(6.6)$ \\
\hline Mean quetelet index $(\mathrm{SD})^{\mathrm{a} *}$ & $19.0(2.5)$ & $20.1(2.7)$ & $20.9(2.8)$ \\
\hline Mean education in years school (SD) & $6.3(3.6)$ & $6.9(3.5)$ & $6.0(3.1)$ \\
\hline \multicolumn{4}{|l|}{ Smoking $(\%)^{\star \star}$} \\
\hline Never smoked & 30.9 & 29.5 & 15.9 \\
\hline Previous smoker & 23.4 & 27.9 & 18.2 \\
\hline Current smoker & 45.7 & 42.6 & 65.9 \\
\hline \multicolumn{4}{|l|}{ Alcohol use $(\%)^{\star \star}$} \\
\hline Never & 23.4 & 31.1 & 15.9 \\
\hline Previous & 24.5 & 13.9 & 11.4 \\
\hline Current & 52.1 & 54.9 & 72.7 \\
\hline $\begin{array}{l}\text { Received training in safe use } \\
\text { of pesticides }(\%)^{\star \star}\end{array}$ & 4.3 & 39.3 & \\
\hline \multicolumn{4}{|l|}{ Use of protective clothing (\%) } \\
\hline Spectacles & 0.0 & 0.8 & \\
\hline Footwear & 1.1 & 0.0 & \\
\hline Gloves & 3.2 & 2.5 & \\
\hline Nose/mouth covering mask & 9.6 & 9.0 & \\
\hline Headgear $^{\star \star}$ & 57.4 & 78.7 & \\
\hline Long-sleeved shirt** & 78.7 & 91.0 & \\
\hline Long pants/sarong ** & 89.4 & 96.7 & \\
\hline $\begin{array}{l}\text { Did never smoke during pesticide } \\
\text { application (\% of smokers) }\end{array}$ & 74.4 & 71.2 & \\
\hline $\begin{array}{l}\text { Did never eat or drink during pesticide } \\
\text { application }(\%)^{\star \star \star}\end{array}$ & 60.6 & 77.9 & \\
\hline
\end{tabular}

SD, standard deviation; IPM, Integrated Pest Management.

${ }^{*} P<0.05$, ANOVA.

${ }^{\star \star} P<0.05$, chi-square.

${ }^{\star \star \star} P<0.005$ chi-square.

${ }^{a}$ Weight/square height $\left(\mathrm{kg} / \mathrm{m}^{2}\right)$.

TABLE II. Self-Reported Acute 0ccupational Pesticide Poisoning in the Past Among General Farmers $(n=94)$ and IPM-Farmers $(\mathrm{n}=122)$ in Sri Lanka

\begin{tabular}{lcc} 
& $\begin{array}{c}\text { General } \\
\text { farmers (\%) }\end{array}$ & $\begin{array}{c}\text { IPM-farmers } \\
\text { (\%) }\end{array}$ \\
\hline Had suffered at least once from an acute occupational pesticide poisoning in the past & $27(29)$ & $25(21)$ \\
$\begin{array}{l}\text { Had suffered at least once from an acute occupational pesticide poisoning in the past } \\
\text { (organophosphate or carbamate symptoms) }\end{array}$ & $16(17)$ & $24(20)$ \\
Had received medical treatment (\% of farmers who had suffered from poisoning) & $14(52)$ & $21(84)$ \\
Had applied some form of self-treatment (\% of farmers who had suffered from poisoning) & $6(22)$ & $4(16)$ \\
Had not sought any treatment (\% of farmers who had suffered from poisoning) & $7(26)$ & $0(0)$ \\
\hline
\end{tabular}


TABLE III. Average Pesticide Spraying Time per Hectare on Different Crops During the Entire Maha Agricultural Season for General Farmers (no IPM) and IPM-Farmers in Sri Lanka

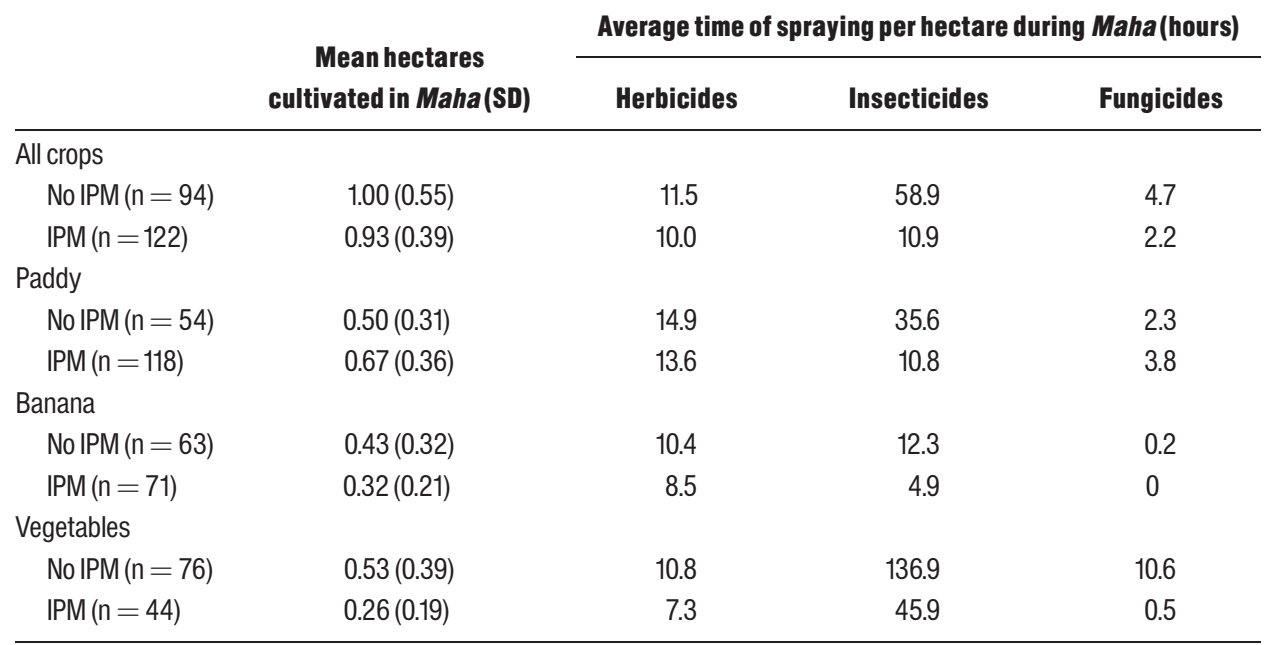

Table IV summarizes mean levels of hemoglobin corrected acetylcholinesterase activity for farmers and controls during low and high exposure seasons as well as acetylcholinesterase inhibition levels. Data were normally distributed. Surprisingly, during the low exposure period (considered baseline levels) the control group showed lower average cholinesterase levels than both groups of farmers (ANOVA, $P<0.05$ ). However, average cholinesterase inhibition during the high exposure season was significantly higher for both groups of farmers (ANOVA, $P<0.001$ ) as compared to controls (3\%). Average inhibition was higher in general farmers than in IPM-farmers (11 and 8\%, respectively; Student's $t$-test, $P<0.01)$. No significant associations were found between cholinesterase inhibition and age, sex, education, smoking, and alcohol use.

Figure 1 shows the cumulative distribution of acetylcholinesterase inhibition among general farmers, IPMfarmers and controls. The order of the three distribution patterns shows that inhibition in general farmers was higher than in IPM-farmers while controls had the lowest inhibition. No inhibition above $27 \%$ was measured in any subject.

Figure 2 shows relationships between cholinesterase inhibition ( $>13 \%$ inhibition, 25 percentile) and determinants in farmers. Not having received IPM training and spraying insecticides more than $13 \mathrm{hr}$ per hectare (median) during the entire Maha season were significantly associated with increased inhibition (Cox's regression, $P<0.05$ ). Other factors such as not having received training in safe use of pesticides, previous poisoning, and not wearing a mask, headgear, or long pants showed weak positive associations with inhibition.

Adjusted prevalence ratios of 16 acute neurological symptoms experienced in the week before the interview during the high exposure period and sixteen Q16 symptoms are shown in Table V. Prevalence of six acute symptoms and two Q16 symptoms differed significantly between farmers

TABLE IV. Acetylcholinesterase Activities (U/g Hemoglobin) and Inhibition Among Sri Lankan Farmers, IPMFarmers, and Fishermen (Controls)

\begin{tabular}{|c|c|c|c|c|c|c|}
\hline & \multicolumn{2}{|c|}{$\begin{array}{l}\text { General farmers } \\
\qquad(n=94)\end{array}$} & \multicolumn{2}{|c|}{$\begin{array}{l}\text { IPM-farmers } \\
\text { (n=122) }\end{array}$} & \multicolumn{2}{|c|}{ Controls $(n=44)$} \\
\hline & Mean & SD & Mean & SD & Mean & SD \\
\hline $\begin{array}{l}\text { Acetylcholinesterase activity during } \\
\text { low exposure period (baseline) }\end{array}$ & 29.15 & 3.88 & 29.20 & 3.95 & 27.68 & 3.43 \\
\hline $\begin{array}{l}\text { Acetylcholinesterase activity during } \\
\text { high exposure period }\end{array}$ & 25.97 & 3.42 & 26.76 & 3.35 & 26.79 & 3.75 \\
\hline Acetylcholinesterase inhibition (\%) ${ }^{\star, \star \star}$ & 10.58 & 7.19 & 8.03 & 6.22 & 3.20 & 5.89 \\
\hline
\end{tabular}

${ }^{\star} P<0.001$, ANOVA.

${ }^{\star} P<0.01$, farmers versus IPM-farmers, Student's $t$-test. 


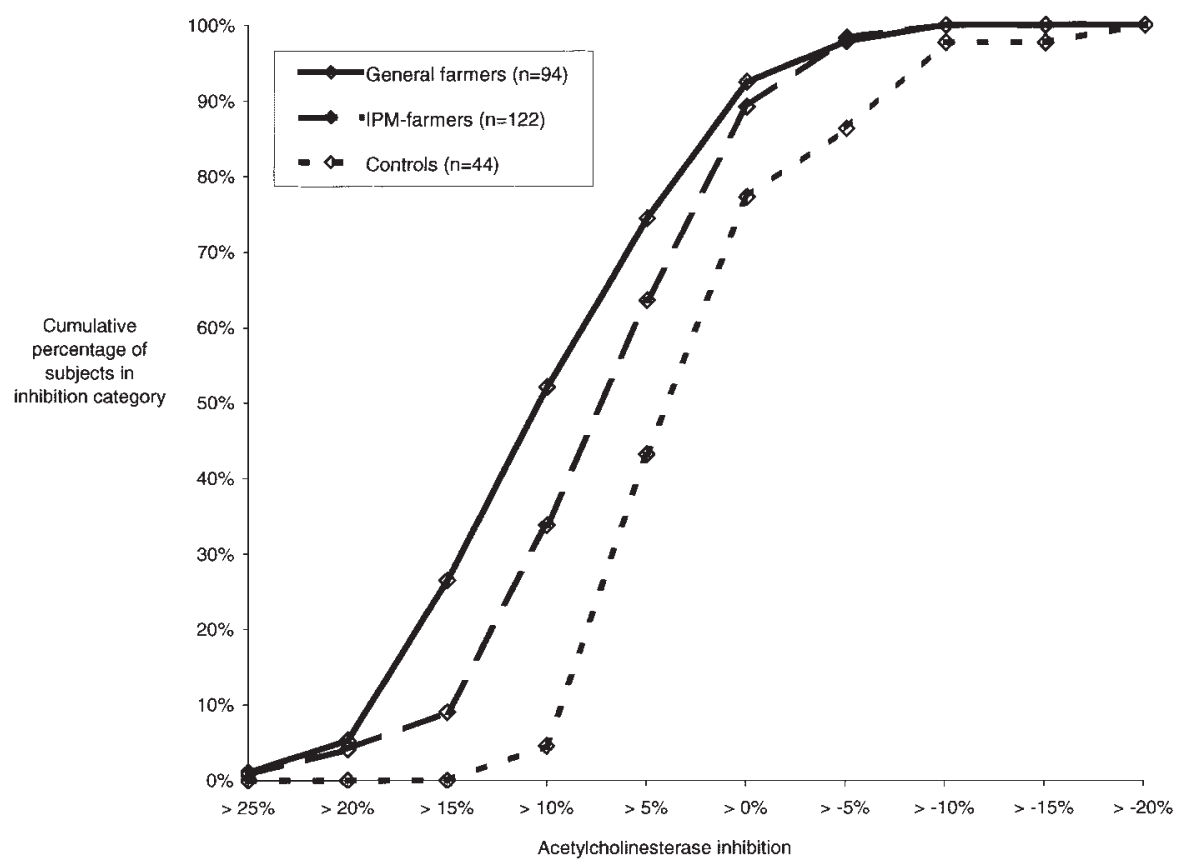

FIGURE 1. Cumulative distribution of acetylcholinesterase inhibition levels among general farmers, Integrated Pest Management (IPM)-farmers, and controls in Sri Lanka.

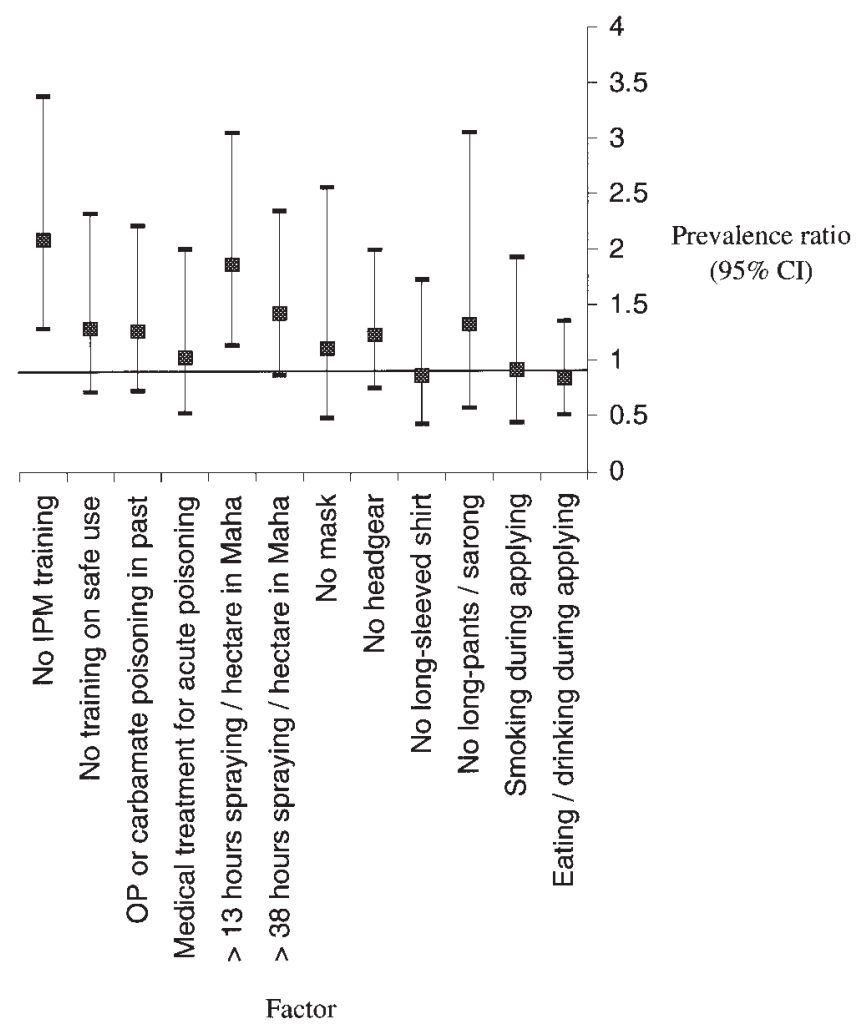

FIGURE 2. Factors possibly associated with increased acetylcholinesterase inhibition inSriLankanfarmers $(n=216)$ (inhibition of $\geq 13 \%$ was used as cut off point). and controls whereas prevalence of three acute symptoms and three Q16 symptoms differed significantly between IPM-farmers and controls (Cox's regression, $P<0.05$ ). Further analysis did not reveal an obvious difference in symptom prevalence for general farmers and IPM-farmers: only one symptom (feelings of fear) was more prevalent among general farmers (the adjusted prevalence ratio (95\% CI) was 2.33 (1.17-4.64). Prevalence of two dummy symptoms, not expected to be associated with pesticide exposure (earache and constipation) did not differ significantly between farmers, IPM-farmers and controls.

Seven of the sixteen acute symptoms (paleness, dizziness, muscle weakness, staggering, feelings of fear, tremor, and nausea) were significantly associated with increased cholinesterase inhibition ( $>13 \%$ inhibition, 25 percentile) after correction for age and education. The adjusted prevalence ratios $(95 \% \mathrm{CI})$ were for paleness $1.50(1.03-2.17)$; dizziness 1.58 (1.07-2.35); muscle weakness 1.67 (1.092.55); staggering 1.86 (1.23-2.80); feelings of fear 2.01 (1.16-3.48); tremor 1.74 (1.14-2.67); and for nausea 1.81 (1.02-3.20). The other acute symptoms, except diarrhea, were also positively associated with increased inhibition with prevalence ratios ranging from 1.05 to 1.73 . Excessive perspiration was the only Q16 symptom significantly associated with increased inhibition (the adjusted PR (95\% CI) was 1.59 (1.09-2.32). The other Q16 symptoms showed weak positive associations with increased inhibition, with prevalence ratios ranging from 1.06 to 1.45 .

Table VI shows the adjusted prevalence ratios for dichotomized acute symptoms, acute symptoms associated with 
TABLE V. Self-Reported Symptoms During High Exposure Period for General Farmers and IPM-Farmers in Sri Lanka With Control Group Used as Reference Category $(n=44)$

\begin{tabular}{|c|c|c|}
\hline \multirow[b]{2}{*}{ Signs and symptoms } & \multicolumn{2}{|c|}{ Adjusted prevalence ratios $(95 \% \mathrm{CI})^{\mathrm{a}}$} \\
\hline & General farmers $(n=94)$ & IPM-farmers $(n=122)$ \\
\hline \multicolumn{3}{|l|}{ Symptoms experienced during last week } \\
\hline Excessive salivation* & $6.56(1.55-27.66)$ & $3.70(0.81-16.80)$ \\
\hline Paleness $S^{\star, \star \star, \star \star \star}$ & $4.35(1.86-10.17)$ & $4.49(1.85-10.85)$ \\
\hline Feelings of fear ${ }^{\star \star \star \star \star}$ & $3.24(1.25-8.45)$ & $1.40(0.47-4.22)$ \\
\hline Staggering ${ }^{\star, \star \star, \star \star \star}$ & $2.70(1.13-6.46)$ & $2.86(1.16-7.05)$ \\
\hline Dizziness ${ }^{\star, \star \star, \star \star \star}$ & $2.63(1.28-5.42)$ & $2.18(1.01-4.73)$ \\
\hline Nausea $a^{\star \star \star}$ & $2.59(0.88-7.61)$ & $2.20(0.70-6.95)$ \\
\hline Muscle weakness ${ }^{\star, \star \star \star}$ & $2.55(1.13-5.77)$ & $2.24(0.95-5.31)$ \\
\hline Nervousness & $1.92(0.98-3.76)$ & $1.82(0.88-3.76)$ \\
\hline Numbness & $1.61(0.92-2.83)$ & $1.69(0.93-3.06)$ \\
\hline Tremor $^{b}$ & $1.51(0.71-3.20)$ & $1.81(0.83-3.92)$ \\
\hline Abdominal pain & $1.50(0.77-2.91)$ & $1.22(0.57-2.58)$ \\
\hline Blurred vision & $1.46(0.87-2.47)$ & $1.54(0.89-2.67)$ \\
\hline Muscle cramps & $1.37(0.66-2.85)$ & $1.15(0.52-2.55)$ \\
\hline Vomiting & $1.31(0.31-5.53)$ & $1.29(0.22-7.63)$ \\
\hline Headache & $0.97(0.60-1.57)$ & $0.99(0.59-1.67)$ \\
\hline Diarrhea & $0.59(0.10-3.60)$ & $1.30(0.24-6.96)$ \\
\hline Earache (dummy symptom) & $2.45(0.70-8.64)$ & $2.77(0.73-10.57)$ \\
\hline \multicolumn{3}{|l|}{ Q16 symptoms } \\
\hline Painful tingling in some parts of the body $y^{\star \star \star \star}$ & $3.05(1.06-8.81)$ & $3.36(1.13-9.98)$ \\
\hline Less interested in sex than what you think is normal ${ }^{\star \star}$ & $2.79(0.82-9.46)$ & $3.62(1.07-12.25)$ \\
\hline Irritated without any particular reasons ${ }^{\star}$ & $2.23(1.08-4.60)$ & $1.84(0.85-3.98)$ \\
\hline Relatives told that you have short memory & $1.74(0.92-3.31)$ & $1.65(0.84-3.23)$ \\
\hline Problems with concentrating & $1.58(0.91-2.73)$ & $1.22(0.67-2.23)$ \\
\hline Often go back and check things ${ }^{\star \star}$ & $1.53(0.85-2.74)$ & $2.04(1.11-3.72)$ \\
\hline Depressed without any particular reasons & $1.51(0.76-2.98)$ & $1.38(0.67-2.83)$ \\
\hline Difficulty breathing ${ }^{b}$ & $1.49(0.70-3.19)$ & $1.79(0.81-3.95)$ \\
\hline Short memory & $1.34(0.80-2.24)$ & $1.39(0.81-2.40)$ \\
\hline Abnormally tired & $1.31(0.81-2.10)$ & $1.30(0.78-2.16)$ \\
\hline Palpitations even without exertion & $1.24(0.63-2.44)$ & $1.35(0.65-2.79)$ \\
\hline Oppression of the chest & $1.16(0.64-2.11)$ & $1.54(0.82-2.87)$ \\
\hline Headache at least once a week & $1.12(0.70-1.79)$ & $1.17(0.70-1.96)$ \\
\hline Trouble falling asleep ${ }^{\mathrm{b}}$ & $1.10(0.68-1.78)$ & $0.93(0.55-1.58)$ \\
\hline Perspiration without any particular reason ${ }^{\star \star \star}$ & $1.08(0.64-1.83)$ & $0.90(0.50-1.62)$ \\
\hline Constipation (dummy symptom) ${ }^{\mathrm{b}}$ & $1.66(0.62-4.50)$ & $0.71(0.23-2.13)$ \\
\hline
\end{tabular}

${ }^{\mathrm{a} A d j u s t e d ~ f o r ~ a g e ~ a n d ~ y e a r s ~ o f ~ e d u c a t i o n . ~}$

${ }^{\mathrm{b}}$ Question different from $\mathrm{Q16}$ of Hogstedt et al. [1984].

${ }^{*} P<0.05$, Cox's regression, general farmers versus controls.

${ }^{\star \star} P<0.05$, Cox's regression, IPM-farmers versus controls.

${ }^{\star \star *} P<0.05$, Cox's regression, $>13 \%$ inhibition.

cholinesterase inhibition and Q16 symptoms related to exposure variables. The crude prevalence ratios differed only slightly from the adjusted prevalence ratios. Farmers had increased prevalence ratios for acute, inhibition related, as well as Q16 symptoms, compared with controls. Cholinesterase inhibition (more than $8 \%$ (median) and more than $13 \%$ (25 percentile)) was significantly associated with increased prevalence of dichotomized acute and inhibition related symptoms among the entire group of farmers and controls. Cholinesterase inhibition above $13 \%$ was also significantly associated with increased acute and inhibition related symptom prevalence among farmers only. Previous organophosphate poisoning and having sprayed insecticides during Maha season were positively though not significantly 
TABLE VI. Factors PossiblyAssociated With16 Acute Organophosphate or Carbamate Exposure Related Symptoms (>6/16), Seven Acute Symptoms Related to Acetylcholinesterase Inhibition (>3/7), and Q16 Symptoms (>6/16) Among Sri Lankan Farmers and Controls

Adjusted prevalence ratios $(95 \% \mathrm{Cl})^{\mathrm{a}}$

\begin{tabular}{|c|c|c|c|}
\hline Factor & Symptoms experienced during last week & Symptoms related to AChE inhibition & Q16 symptoms \\
\hline \multicolumn{4}{|l|}{ Farmers and controls $(n=260)$} \\
\hline Farmers versus controls & $2.85(1.21-6.74)^{\star}$ & $5.04(1.55-16.38)^{\star}$ & $1.59(0.93-2.70)$ \\
\hline Cholinesterase inhibition $\geq 8 \%$ (median) & $1.60(1.03-2.47)^{\star}$ & $1.65(1.02-2.66)^{\star}$ & $1.06(0.76-1.46)$ \\
\hline Cholinesterase inhibition $\geq 13 \%$ ( 25 percentile) & $2.02(1.32-3.08)^{\star}$ & $2.54(1.60-4.02)^{\star}$ & $1.22(0.86-1.73)$ \\
\hline \multicolumn{4}{|l|}{ Farmers only $(n=216)$} \\
\hline Did not receive IPM training & $1.24(0.75-2.03)$ & $1.31(0.77-2.23)$ & $1.04(0.70-1.54)$ \\
\hline Cholinesterase inhibition $\geq 8 \%$ (median) & $1.41(0.89-2.23)$ & $1.41(0.86-2.31)$ & $1.04(0.73-1.48)$ \\
\hline Cholinesterase inhibition $\geq 13 \%$ ( 25 percentile) & $1.79(1.15-2.79)^{\star}$ & $2.14(1.33-3.44)^{\star}$ & $1.15(0.79-1.66)$ \\
\hline $\begin{array}{l}\text { Suffered from acute pesticide poisoning in the } \\
\text { past (OP or carbamate poisoning symptoms) }\end{array}$ & $1.54(0.92-2.55)$ & $1.42(0.83-2.42)$ & $1.16(0.75-1.79)$ \\
\hline $\begin{array}{l}\text { Received medical treatment for acute pesticide } \\
\text { poisoning in the past }\end{array}$ & $1.49(0.87-2.55)$ & $1.42(0.80-2.55)$ & $0.95(0.58-1.54)$ \\
\hline $\begin{array}{l}\text { Sprayed insecticides more than } 13 \mathrm{hr} \text { per hectare } \\
\text { during Maha season (median) }\end{array}$ & $1.18(0.74-1.88)$ & $1.16(0.70-1.90)$ & $1.11(0.77-1.61)$ \\
\hline $\begin{array}{l}\text { Sprayed insecticides more than } 38 \mathrm{hr} \text { per hectare } \\
\text { during Maha season ( } 75 \text { percentile) }\end{array}$ & $1.22(0.75-1.98)$ & $1.15(0.68-1.95)$ & $1.07(0.72-1.59)$ \\
\hline
\end{tabular}

${ }^{\mathrm{a} A d j u s t e d ~ f o r ~ a g e ~ a n d ~ y e a r s ~ o f ~ e d u c a t i o n . ~}$

${ }^{\star} P<0.05$, Cox's regression.

associated with increased prevalence of the dichotomized symptoms.

\section{DISCUSSION}

This study showed that a group of Sri Lankan farmers had significantly higher red blood cell cholinesterase inhibition during a high pesticide exposure period than a control group of fishermen. The higher inhibition among farmers was obviously due to occupational insecticide exposure since no other environmental exposures are known that lower erythrocyte cholinesterase [Ciesielski et al., 1994]. Farmers who had followed an IPM-demonstration had less cholinesterase inhibition than farmers not trained in IPM, probably because they sprayed significantly fewer insecticides. Farming was also associated with higher prevalence of both acute and chronic symptoms related to pesticide exposure. The acute symptoms were positively and significantly associated with acetylcholinesterase inhibition (more than 13\% inhibition; $P<0.05)$. Dichotomized acute symptoms and acute symptoms associated with cholinesterase inhibition showed a dose-response relationship for cholinesterase inhibition and symptom prevalence. Although Q16 symptoms were more prevalent in farmers than in controls, no relationships existed between Q16 prevalence and inhibition, spraying insecticides in Maha season or IPM-farming, probably because these factors do not reflect chronic exposure to insecticides.
Several forms of bias could have affected the outcome of the study. However, it is unlikely that selection bias influenced the results since all invited farmers and controls agreed to participate. In addition, the initial and final study population was comparable regarding personal characteristics, symptoms and baseline cholinesterase level. Responder bias could have played a role because objectives of the study were explained to all participants. Farmers might have over-reported their health complaints because they were aware of the problem of pesticide exposure. However, dummy symptoms showed similar prevalence for both groups, thus it is unlikely that the relationships between farming and symptom prevalence is due to responder bias.

Poor recall of spray activities during the previous month (especially pesticides' names) affected associations between spraying, and cholinesterase inhibition or symptoms. As it was essential to know whether organophosphates or carbamates were involved it was not possible to use this information as a marker of exposure. It was expected that farmers who frequently sprayed pesticides during the entire preceding Maha season would also be more high by exposed during Yala. However, a dose-response relationship for spraying insecticides during the preceding Maha season and acetylcholinesterase inhibition was not seen, probably explaining the absence of a clear relationship between spraying and symptom prevalence. Acetylcholinesterase inhibition was, therefore, a better proxy for recent exposure to cholinesterase-inhibiting insecticides than self-reported 
spray-activities during either Maha season or the previous month. It is unlikely that differences found between general farmers and IPM-farmers with regard to insecticide use during Maha season are due to information bias because reported use of other pesticides was similar.

As other factors may also be related to the symptomquestionnaires it was important to control for potentially confounding factors such as age, sex, alcohol use, smoking, educational level, previous organophosphate poisoning, and nutritional status. The prevalence of most symptoms was higher among both farmers and controls, probably due to a low level of standard of living. Although age did not meaningfully affect the results after correction, it was decided to keep it in the regression model. Alcohol intake and tobacco consumption was high for all study subjects, however adjustment for alcohol and tobacco did not meaningfully change associations with symptoms. Subjects who had suffered from organophosphate poisoning showed a (nonsignificantly) elevated symptom prevalence, possibly as a sequel of acute poisoning. However, it was decided not to correct for previous poisoning as it did not meaningfully change symptom prevalence ratios. Lower educational level (total years) was the only potential confounding factor that was significantly related to increasing symptom prevalence.

Cholinesterase inhibition among farmers was lower than in a study conducted in Kenya where an average inhibition level of 35\% was found among exposed farm workers [Ohayo-Mitoko et al., 2000]. This difference might be due to different timing of taking blood samples; in the Kenyan study blood samples of pesticide applicators of both small and large-scale farms were obtained at the end of work shifts whereas data collection in Sri Lanka took place per village. Also, the Sri Lankan farmers were used to spraying on an irregular basis and not all farmers had recently been exposed to organophosphates or carbamates at the time of blood sampling, which could explain the relatively low average inhibition of $9 \%$. Surprisingly the control group had a lower average cholinesterase activity than both groups of farmers during the low exposure period. Possibly the production of cholinesterase among farmers is increased because of their repeated exposure to cholinesterase-inhibiting pesticides; human beings may develop a compensation mechanism and therefore, farmers may have higher cholinesterase levels than controls in low exposure periods [Ciesielski et al., 1994]. The WHO recommends $30 \%$ cholinesterase inhibition as the level for removal of workers from exposure [IPCS, 1986]. The Kenyan study suggested that increased respiratory, eye, and central nervous system symptom prevalence might occur at cholinesterase inhibition levels below this level, which is in agreement with the findings of this study.

The group of farmers that had attended IPM demonstrations reported considerably less insecticide use than general farmers. Promotion and implementation of intensive, participatory IPM training (e.g., the Farmer Field School concept) may be a sustainable approach to reduce insecticide use even more. Although IPM-farmers experienced lower cholinesterase inhibition than general farmers, and somewhat lower acute symptoms prevalence, insecticide exposure still seemed to result in depressed cholinesterase levels and increased symptom prevalence.

Protective clothing and determinants of hygienic behavior were not related to the level of ACh-inhibitions. However, our study design was not appropriate for the evaluation of protective measures and therefore, no conclusion can be drawn from these results. Intervention studies should be performed to evaluate the effect of control measures.

The Mahaweli Authority of Sri Lanka promotes crop diversification from paddy, towards banana and vegetables as a water saving strategy in Uda Walawe. According to this study, insecticide use per hectare is much higher in vegetables than in paddy and banana so the promotion of crop diversification towards vegetables could have a negative impact on the health of farmers in Uda Walawe while diversification towards banana could have a positive impact.

Our results suggest that occupational acetylcholinesterase-inhibiting insecticide exposures have a negative impact on the health of farmers in Uda Walawe. A high proportion (24\%) of farmers suffered at least once from acute occupational pesticide poisoning in the past. Insecticide use seemed to result in depressed cholinesterase levels and cholinesterase inhibition was associated with increased acute symptom prevalence. IPM training seemed to result in less insecticide use, and less cholinesterase inhibition ( 8 vs. $11 \%$; $P<0.01$ ). However, only a small effect of IPM training on the prevalence of acute pesticide-related symptoms could be determined and no effect was found for chronic neurological symptom prevalence.

\section{ACKNOWLEDGMENTS}

We are grateful to Buul Docters van Leeuwen, Henk van den Berg, and Roísín O'Kane for advise; Mala Ranawake, Sepali Goonaratne, Chandani Deepika, and Ravi Karunaratne for technical assistance; and all study participants for collaborating.

\section{REFERENCES}

Al-Shatti AK, El-Desouky M, Zaki R, Abu-Al-Azem M, Al-Lagani M. 1997. Health care for pesticide applicators in a locust eradication campaign in Kuwait (1988-1989). Environ Res 73:219-226.

Brouwer DH, De Vreede JAF, Meuling WJA, Van Hemmen JJ. 2000. Determination of the efficiency for pesticide exposure reduction with protective clothing: A field study using biological monitoring. In: Honeycutt HC, editor. Worker exposure to agrichemicals. Batton Rouge, FL: ACS Symposium Series, CRC, Lewis Publishers. pp 65-86.

Ciesielski S, Loomis DP, Rupp Mims S, Auer A. 1994. Pesticide exposures, cholinesterase depression, and symptoms among North Carolina migrant farmworkers. Am J Public Health 84:446-451. 
Derogatis LR, Spencer PM. 1982. The brief symptom inventory (BSI). Administration, scoring, and procedures manual-I. Baltimore: John Hopkins University School of Medicine.

Eddleston M, Rezvi Sheriff MH, Hawton K. 1998. Deliberate self-harm in Sri Lanka: An overlooked tragedy in the developing world. Br Med J 317:133-135.

Ellman GL, Courtney KD, Andres JV, Featherstone RM. 1961. A new and rapid colorimetric determination of acetylcholinesterase activity. Biochem Pharmacol 7:88-95.

FAO Programme for Community IPM in Asia. 2001. www.communityipm.org. Accessed 25th September 2001.

Fernando A, Hewagalage C. 1999. Pesticide problems in Sri Lanka. Pestic Monit 8:6-7.

Hogstedt C, Andersson K, Hane M. 1984. A questionnaire approach to the monitoring of early disturbances in central nervous functions. In:Aito A, Rihimaki V, Vainio H. editors. The biological monitoring of exposure to industrial chemicals. Washington: Hemisphere. pp 275-287.

IPCS. 1986. Environmental health criteria 63; organophosphorus insecticides. Geneva, Switzerland: World Health Organization. p 181.

Jeyaratnam J, De Alwis Seneviratne RS, Copplestone JF. 1982. Survey of pesticide poisoning in Sri Lanka. Bull World Health Organ 60:615619.

Kishi M, Hirschhorn N, Djajadisastra M, Satterlee LN, Srowman S, Dilts R. 1995. Relationship of pesticide spraying to signs and symptoms in Indonesian farmers. Scand J Work Environ Health 21:124-133.

London L, Nell V, Thompson M, Myers JE. 1998. Effects of long-term organophosphate exposures on neurological symptoms, vibration sense, and tremor among South African farm workers. Scand J Work Environ Health 24:18-29.

Lundberg I, Högberg M, Michélsen H, Nise G, Hogstedt C. 1997. Evaluation of the Q16 questionnaire on neurotoxic symptoms and a review of its use. Occup Environ Med 54:343-350.

Maroni M, Colosio C, Fait A, Visentin S. 1999. Occupational exposure to pesticides in the developing world: Health effects and strategies for prevention. Asian-Pacific Newslett Occup Health Safety 6: 68-71.

Meuling WJA, Franssen AC, Brouwer DH, Van Hemmen JJ. 1997. The influence of skin moisture on the dermal absorption of propoxur in human volunteers. A consideration for biological monitoring practices. Sci Total Environ 199:165-172.

Ministry of Health. 2001. Annual health bulletin Sri Lanka, 1999. Colombo, Sri Lanka.

Namba T. 1971. Cholinesterase inhibition by organophosphorus compounds and its clinical effects. Bull World Health Organ 44:289307.
Ohayo-Mitoko GJA, Kromhout H, Simwa JM, Boleij JSM, Heederik D. 2000. Self reported symptoms and inhibition of acetylcholinesterase activity among Kenyan agricultural workers. Occup Environ Med 57: 195-200.

Rola AC, Pingali PL. 1993. Pesticide exposure, farmers' health, and choice of pest control technologies. In: Rola AC, Pingali PL, editors. Pesticides, rice productivity, and farmers' health. Manila, Philippines: IRRI. pp 55-64.

Rosenstock L, Keifer M, Daniell WE, McConnell R, Claypoole K. 1991. Chronic central nervous system effects of acute organophosphate pesticide intoxication. Lancet 338:223-227.

Sivayoganathan C, Gnanachandran S, Lewis J, Fernando M. 1995. Protective measure use and symptoms among agropesticide applicators in Sri Lanka. Soc Sci Med 40:431-436.

Skov T, Deddens J, Petersen MR, Endahl L. 1998. Prevalence proportion ratios: Estimation and hypothesis testing. Int J Epidemiol 27:91-95.

Spruit O, van Puyvelde M. 1998. Evaluation of the protective equipment used during herbicide application on banana plantations. Internal report No. 304. Wageningen, The Netherlands: Environmental and Occupational Health Group, Wageningen University.

Stephens R, Spurgeon A, Calvert IA, Beach J, Levy LS, Berry H, Harrington JM. 1995. Neuropsychological effects of long-term exposure to organophosphates in sheep dip. Lancet 345:1135-1139.

Tinoco-Ojanguren R, Halperin DC. 1998. Poverty, production, and health: Inhibition of erythrocyte cholinesterase via occupational exposure to organophosphate insecticides in Chiapas, Mexico. Arch Environ Health 53:29-35.

Van der Hoek W, Konradsen F, Athukorala K, Wanigadewa T. 1998 Pesticide poisoning: A major health problem in Sri Lanka. Soc Sci Med 46:495-504.

van Wendel de Joode BN, de Graaf IAM, Wesseling C, Kromhout H. 1996. Paraquat exposure of knapsack sprayers on banana plantations in Costa Rica. Int J Occup Environ Health 2:294-304.

Wesseling C, Keifer M, Ahlblom A, McConnell R, Moon JD, Rosenstock L, Hogstedt C. 1997. Long-term neurological effects of mild poisoning with organophosphate and n-methyl carbamate pesicides among banana workers. In: Wesseling $\mathrm{C}$, editor. Health effects from pesticide use in Costa Rica - an epidemiologic approach Stockholm, Sweden: Division of Epidemiology, Institute of Environmental Medicine, Karolinska Institute.

WHO. 2001. The WHO recommended classification of pesticides by hazard and guidelines to classification 2000-2001. Geneva, Switzerland: World Health Organization.

Xue SZ. 1987. Health effects of pesticides: A review of epidemiologic research from the perspective of developing nations. Am J Ind Med 12:269-279.

Yuknavage KL, Fenske RA, Kalman DA, Keifer M, Furlong CE. 1997. Simulated dermal contamination with capillary samples and field cholinesterase biomonitoring. Toxicol Environ Health 51:35-55.

\section{APPENDIX}

Pesticides Used Last Month During Baseline and Yala Season by General Farmers (no IPM, 275 Spray Operations) and IPM-Farmers (IPM, 239 Spray Operations) in Sri Lanka

\begin{tabular}{lccc}
$\begin{array}{l}\text { Chemical type and common } \\
\text { name of pesticide }\end{array}$ & WHO classification & $\begin{array}{c}\text { No IPM, percentage of } \\
\text { all spray operations }\end{array}$ & $\begin{array}{c}\text { IPM, percentage of } \\
\text { all spray operations }\end{array}$ \\
\hline Insecticides & 71.3 & 53.7 \\
OP/carbamate insecticides & 40.4 & 34.4 \\
Herbicides & 23.6 & 38.0 \\
Fungicides & 5.1 & 8.3
\end{tabular}


APPENDIX (Continued)

Chemical type and common name of pesticide

Organophosphate insecticides

Chlorpyrifos

Fenthion

Dimethoate

Phenthoate

Profenophos

Quinalphos

Prothiophos

Methamidophos

Oxydemeton-methyl

Monocrotophos

Edifenphos (fungicide)

Diazinon

Carbamate insecticides

Carbosulfan

Methomyl

Fenobucarb (BPMC)

Carbofuran

Carbaryl

Thiodicarb

Organochlorine insecticides

Endosulfan

Pyrethroid insecticides

Permethrin

Deltamethrin

Ethofenprox

Fenvalerate

Other insecticides

Herbicides

Glyphosate

Propanil

Paraquat

MCPA

Other herbicides

Fungicides

Thiophanate-methyl

Sulfur

Captan

Benomyl

Other fungicides
No IPM, percentage of

WHO classification ${ }^{\mathrm{a}}$
IPM, percentage of

all spray operations
12.6

0.8

5.9

0.4

2.5

1.7

0.0

1.3

0.0

0.0

1.7

0.4

0.4

1.3

2.1

2.9

0.0

0.4

0.8

0.8

0.0

0.0

1.3

16.3

2.5

12.6

3.3

9.6

10.0

$\begin{array}{lr}2.9 \\ 2.2 & 10.0\end{array}$

$\begin{array}{ll}1.8 & 0.8\end{array}$

$1.1-13$

$0.7 \quad 0.4$

$\begin{array}{ll}0.4 & 0.8\end{array}$

$1.1 \quad 5.0$

Pesticides were mostly applied by backpack spraying

Pesticides are classified as Class la (extremely hazardous), Class Ib (highly hazardous), Class II (moderately hazardous), Class III (slightly hazardous), Table V (0) (unlikely to present acute hazard in normal use) [WHO, 2001].

The WHO bases its acute hazard classification on the lowest published rat oral LD50, the lethal dose (in milligrams of substance per kilogram of body weight) that kills $50 \%$ of the test animals in a standard assay. 